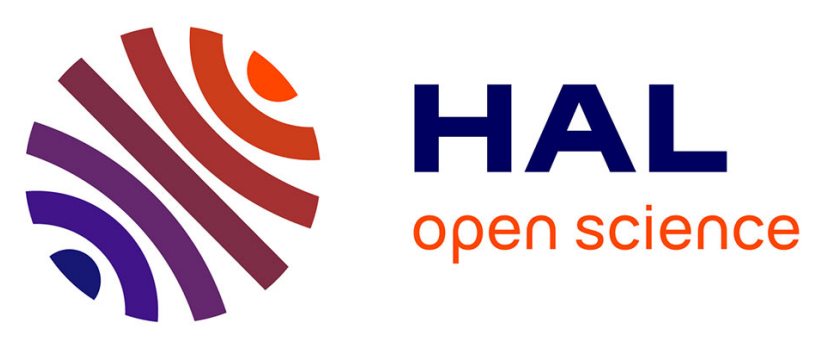

\title{
Astronomical calibration of the Early Oxfordian (Vocontian and Paris basins, France): Consequences of revising the Late Jurassic time scale.
}

Slah Boulila, Linda A. Hinnov, Emilia Huret, Pierre-Yves Collin, Bruno

Galbrun, Dominique Fortwengler, Didier Marchand, Jacques Thierry

\section{To cite this version:}

Slah Boulila, Linda A. Hinnov, Emilia Huret, Pierre-Yves Collin, Bruno Galbrun, et al.. Astronomical calibration of the Early Oxfordian (Vocontian and Paris basins, France): Consequences of revising the Late Jurassic time scale.. Earth and Planetary Science Letters, 2008, 276 (1-2), pp.40-51. 10.1016/j.epsl.2008.09.006 . hal-00541029

\section{HAL Id: hal-00541029 \\ https://hal.science/hal-00541029}

Submitted on 3 May 2021

HAL is a multi-disciplinary open access archive for the deposit and dissemination of scientific research documents, whether they are published or not. The documents may come from teaching and research institutions in France or abroad, or from public or private research centers.
L'archive ouverte pluridisciplinaire HAL, est destinée au dépôt et à la diffusion de documents scientifiques de niveau recherche, publiés ou non, émanant des établissements d'enseignement et de recherche français ou étrangers, des laboratoires publics ou privés. 


\title{
Astronomical calibration of the Early Oxfordian (Vocontian and Paris basins, France): Consequences of revising the Late Jurassic time scale
}

\author{
Slah Boulila ${ }^{a}$, Linda A. Hinnov ${ }^{b}$, Emilia Huret ${ }^{\text {b,c }}$, Pierre-Yves Collin ${ }^{a}$, Bruno Galbrun ${ }^{a, *}$, \\ Dominique Fortwengler ${ }^{\mathrm{d}}$, Didier Marchand ${ }^{\mathrm{e}}$, Jacques Thierry ${ }^{\mathrm{e}}$ \\ a Université Paris VI, CNRS - UMR 7072 Tectonique, case 117, 4 place Jussieu, 75252 Paris cedex 5, France \\ ${ }^{b}$ Morton K. Blaustein Department of Earth and Planetary Sciences, Johns Hopkins University, 3400 North Charles Street, Baltimore, Maryland 21218, USA \\ c ANDRA DS/Milieu Géologique, 1/7, rue Jean Monnet, F-92290 Châtenay-Malabry Cedex, France \\ ' Le Clos des Vignes, Quartier Pierry, F-26160 La Bégude de Mazenc, France \\ e Université de Bourgogne, UMR 5561 Biogéosciences, 6 Boulevard Gabriel, 21000 Dijon, France
}

\begin{abstract}
Magnetic susceptibility (MS) variations record Earth's orbital parameters in the clays and marls of the Early Oxfordian in the Paris and Vocontian basins of France. Climatically driven weathering of surrounding emergent areas and the resulting detrital input to the basins is a significant source of the MS signal. MS proves to be an effective tool for deciphering the orbital forcing signal in these sediments, and for assessing the chronology of these formations. The 405-kyr orbital eccentricity cycle is clearly visible in the MS signal and, consequently, is a valuable geochronometer for this portion of the Jurassic time scale. Astronomical calibration of the Mariae ammonite zone (basal Oxfordian stage) indicates a duration of 2.2 myrs, whereas current time scales assign only 0.6 myrs to this biozone. However, the Late Jurassic time scale has large uncertainties in stage boundary ages ( \pm 4 myrs), hence of interval durations. These results could lead to significant revisions in the M-sequence magnetic anomaly block model, and greatly improve the resolution of the Jurassic time scale.
\end{abstract}

\section{Introduction}

The Geologic Time Scale 2004 (GTS2004, Gradstein et al., 2004) reveals significant and numerous uncertainties, which impact the interpretation of major geologic events: velocities of plate motions, sediment accumulation rates, paleoclimatic change, biological evolution, and geochemical cycling. Thus, geoscientists need to refine GTS2004 to improve research into our planet's history.

A particularly poorly constrained Phanerozoic geological interval is the Late Jurassic, which has the largest uncertainties in the Phanerozoic time scale, with stage boundary ages estimated with $2 \sigma$ uncertainties on the order of \pm 4 myrs (Hinnov and Ogg, 2007). A paucity of radiometric dating and the low amplitudes of the oldest marine magnetic anomalies contribute significantly to these uncer-

\footnotetext{
* Corresponding author. Tel.: +33 144275041; fax: +33 144273831.

E-mail addresses: slah.boulila@upmc.fr (S. Boulila), hinnov@jhu.edu (L.A. Hinnov), Emilia.huret@andra.fr (E. Huret), pierre-yves.collin@upmc.fr (P.-Y. Collin), bruno.galbrun@upmc.fr (B. Galbrun), dominique.fortwengler@wanadoo.fr (D. Fortwengler), didoux.marchand@gmail.com (D. Marchand), jacques-thierry2@wanadoo.fr (J. Thierry).
}

tainties. Here we tackle the problem of the virtually unconstrained time scale of the Mariae ammonite zone that defines the lower boundary of the Oxfordian stage.

Our investigation centers on astronomical calibration of the Terres Noires Formation at Aspres-sur-Buëch, Vocontian Basin, SE France (Fig. 1). The formation presents a thick sequence of cyclic clayey and marly sediments of latest Bathonian to Oxfordian age (Artru, 1972; Tribovillard, 1988). This cyclic sequence was deposited at an exceptionally high sedimentation rate (e.g., Dardeau et al., 1988), thus providing a very high stratigraphic resolution with relatively few hiatuses (Fortwengler and Marchand, 1994). We approach the Late Jurassic time scale problem with a cyclostratigraphic analysis of $333 \mathrm{~m}$ of the earliest Oxfordian Terres Noires encompassing the Mariae Zone. Thus, we use magnetic susceptibility as a proxy for paleoclimate change (e.g., Weedon et al., 1999; Boulila et al., 2008a). This section is greatly expanded compared to the Polish condensed sections (only $13 \mathrm{~cm}$ and $20 \mathrm{~cm}$ ) that were used in the construction of GTS2004 (Ogg et al., 1991). To support our interpretation, we compare the Aspressur-Buëch section with its equivalent in the EST342 ANDRA core from the eastern Paris Basin, $400 \mathrm{~km}$ to the northwest (Fig. 1). In this core, the Mariae Zone is only 25-m thick and was recently biostratigraphically defined to the horizon scale (the thinnest stratigraphic unit 
characterized by a distinctive ammonite association within which no finer subdivision is possible), with both lower and upper boundaries precisely recognized at the $\mathrm{cm}$ scale (Thierry et al., 2006).

This paper aims first at the demonstration of the orbitally forced stratigraphy in the Paris and Vocontian basins (Oxfordian, Mariae ammonite zone). Thus, we applied spectral analysis to assess nonrandom variations in the MS series obtained from both localities, and to understand the distribution of signal variance as a function of frequency. To assess the behavior of specific astronomical frequencies, we applied filtering and time-frequency techniques, and compared the results to the astronomical model of Laskar et al. (2004). Then, we astronomically calibrated the duration of the Mariae Zone. The results report on our multiple working hypothesis approach and decision making us propose a greatly expanded time scale for the Mariae Zone, i.e., not 0.6-myr long as assigned by GTS2004, but 2.2 myrs in duration. Finally, we discuss the consequences of the longer time scale, as indicated by these cyclostratigraphic sections, on the estimated rates and timing of geologic events and processes that were occurring during the Late Jurassic.

\section{Geologic setting and stratigraphic framework}

\subsection{Geologic setting}

The Vocontian Basin of southeastern France (Fig. 1) experienced the effects of significant global changes. These changes include a worldwide carbonate production crisis (Norris and Hallam, 1995) and extensive deposition of argillaceous sediments or iron oolitic condensed sections (de Graciansky et al., 1999; Collin et al., 2005). These environmental changes may have been induced by a global sealevel rise (e.g., Hallam, 1988; Norris and Hallam, 1995) and a major perturbation of the surface carbon cycling. The latter may have been a response to an increase in atmospheric carbon dioxide from possible volcanic effusions (e.g., Dromart et al., 2003).

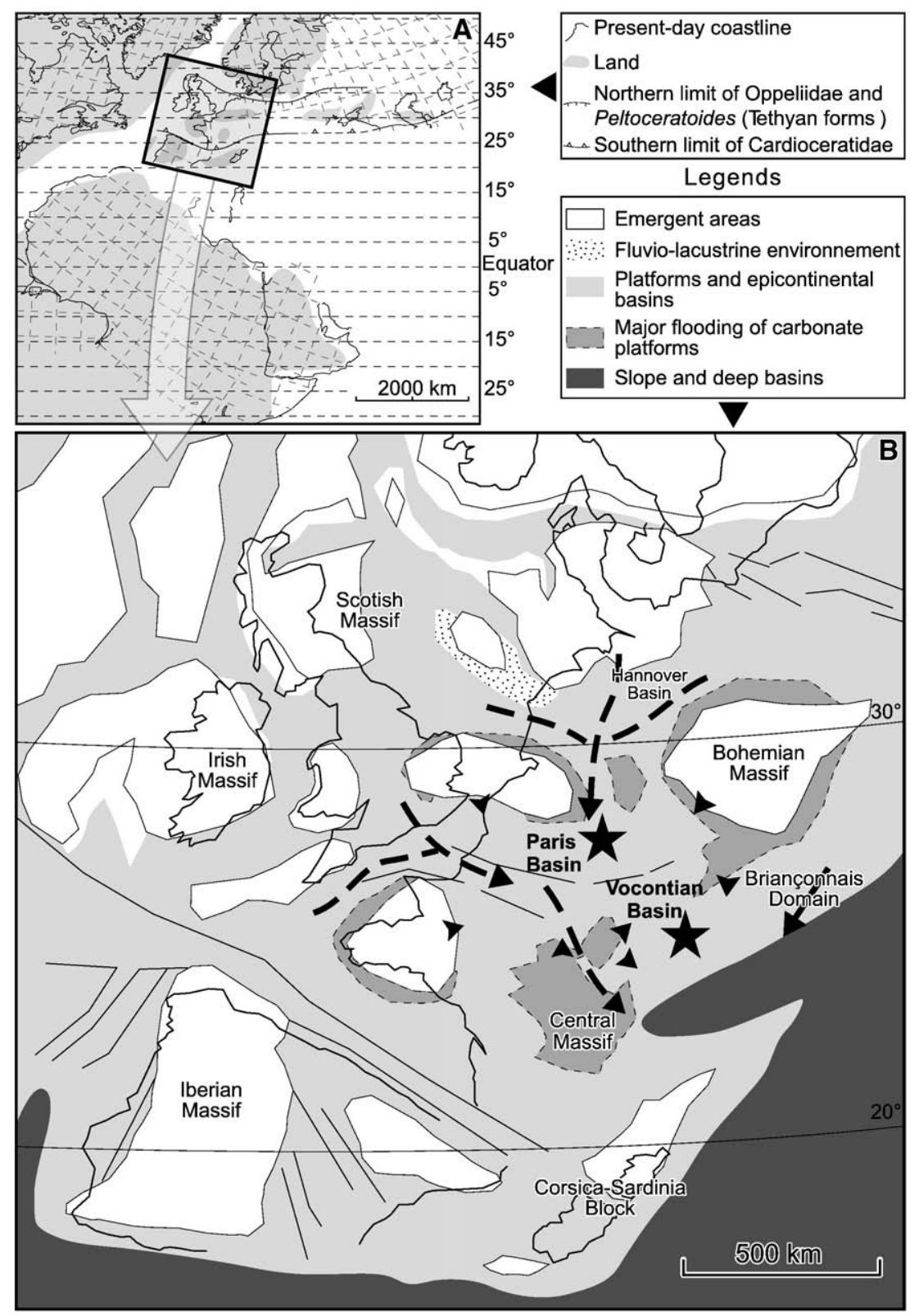

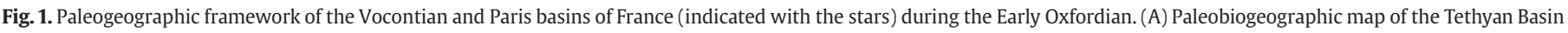

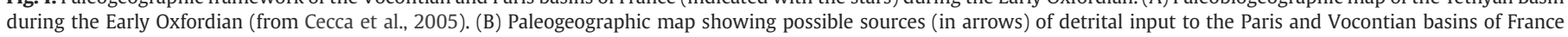
(modified from Pellenard, 2003 and Dercourt et al., 1993). 
Hundreds of meters of clayey and marly sediments (the Terres Noires Formation) were deposited in the central Vocontian Basin where subsidence was apparently the highest during the Early Oxfordian, particularly during the Mariae Zone, Scarburgense Subzone (de Graciansky et al., 1999). Subsidence was the result of Tethyan and North Atlantic rifting (Dardeau et al., 1988). Sedimentation of the Terres Noires Formation was continuous and today provides a sensitive record of hydrologic weathering from the surrounding emergent areas (Debrand-Passard et al., 1984; Dercourt et al., 1993). Consequently, it is an ideal area for geodynamic, paleogeographic and paleoclimatic studies. In addition, the Terres Noires Formation has preserved a number of volcanic ash layers. Several bentonite horizons were recently discovered in the Terres Noires and their equivalents in the eastern Paris Basin, $400 \mathrm{~km}$ to the northwest, in the overlying Cordatum and Plicatilis ammonite zones (Pellenard et al., 2003). These ashes may yield radiometric dates, which together with the astronomical calibration undertaken in this study will offer a new high-resolution absolute time framework.

During the Late Jurassic, the Paris Basin (Fig. 1) was an intracratonic basin created by dislocation and extension of the West European craton from the combined influences of the opening North Atlantic Rift, Tethys Ocean, and North Sea (Dercourt et al., 1985; Curnelle and Dubois, 1986; Ziegler, 1988). In the northwestern Tethys, the Early Callovian was characterized by carbonate environments and siliciclastic platforms. A major change occurred in the Middle-Late Callovian and persisted into the Early Oxfordian, marked by the disappearance of carbonate platforms and the onset of copious terrigenous sedimentation into the basins. During this period, the eastern Paris Basin received continuous deposition of a thick argillaceous series $(\sim 150 \mathrm{~m})$. This clayey formation, called the Callovian-Oxfordian argillites, spans the Middle-Late Callovian to Middle Oxfordian and reflects a shelf marine environment (Collin and Courville, 2006; Ferry et al., 2007). The formation includes a major maximum flooding surface situated near the base of the Oxfordian stage in the Mariae Zone (Jacquin et al., 1998; Courville and Collin, 2002; Ferry et al., 2007). In the Middle Oxfordian, carbonate platforms became newly established and contributed to increased carbonate deposition into the basin and the formation of alternating marllimestone successions (Lorin et al., 2004; Collin et al., 2005; Ferry et al., 2007).

The record of the changes in terrigenous fluxes from the Early Callovian to the Early Oxfordian implies the presence of a palaeogeographic barrier between the eastern Paris Basin and the Vocontian Basin, with two distinct detrital sources (Fig. 1; Pellenard and Deconinck, 2006).

\subsection{Stratigraphic framework}

\subsubsection{Aspres-sur-Buëch section}

The Aspres-sur-Buëch section is located $\sim 3.5 \mathrm{~km}$ to the west of Aspres-sur-Buëch village near the Callovian-Oxfordian synsedimentary fault of Aspremont (Dardeau et al., 1988). The section spans the Early Callovian to Late Oxfordian. Here we focus on the more continuously exposed and well dated interval encompassing the Mariae ammonite zone of the earliest Oxfordian. An abundant ammonite fauna provides a well constrained biostratigraphic framework (Fig. 2B); the uppermost part of the Mariae Zone, however, has not been precisely identified (Fortwengler and Marchand, 1994).

The section (Fig. 2C) records a $333-\mathrm{m}$ thick interval of the Mariae Zone. The lithology is composed of grey marls with low carbonate content (10 to $32 \%)$ and low organic matter content $(<0.8 \%$ TOC) mainly derived from terrestrial erosion (Tribovillard, 1988). An enrichment of the marls with carbonate is observed in the uppermost part of the section. Calcareous nodules with oblate ellipsoidal shapes (5 to 10-cm thick) are aligned parallel to the strata. These nodules are rare in the lower part of the section, and abundant from 180 to $\sim 280 \mathrm{~m}$. Locally in the upper part of the section, calcareous septariatype nodules with a variety of shapes (round, spiral, tubular) are dispersed within the marls. Phosphate nodules occur in the uppermost part of the scarburgense horizon, the uppermost woodhammense horizon, and within the praecordatum horizon (Huret, 2006). Some levels in the marls include $\mathrm{cm}$-thick calcareous layers. Finally, three intervals with distal tempestites (each 1 to 2 -cm thick) were recognized within the marls (labelled T1, T2, and T3, Fig. 2C).

Subtle color variations in darkness versus lightness are occasionally observed in the lower part of the section; these become prominent toward the top of the section due to the increase in carbonate content. The uppermost $6 \mathrm{~m}$ consists of alternating carbonate-rich/ carbonate-poor layers in decimeter-scale couplets. Elsewhere in the basin, Tribovillard $(1986,1988)$ and Tribovillard and Ducreux (1986) describe 0.3 to 2 -m thick bundles of light/dark grey marl alternations and superbundles composed of four bundles. They explain this bundling as due to cyclic variations of terrestrial clay and organic matter input versus marine carbonate production and interpret it as expressions of the $\sim 100$ and $400 \mathrm{kyr}$ orbital eccentricity cycles.

De Graciansky et al. (1999) assigned a single third-order depositional sequence [Ox0-Ox1] to the Mariae Zone of the Terres Noires Formation (Fig. 2C). Sequence boundary Ox0 was assigned to the lower boundary of the Mariae Zone (i.e., the Callovian/Oxfordian boundary), and sequence boundary Ox1 was placed within the Praecordatum Subzone. The maximum flooding surface (MFS) of [Ox0-Ox1] corresponds to a major surface recognized in the western European basins within the Scarburgense Subzone (Jacquin et al., 1998). The opening of the Tethyan and North Atlantic oceans (Dardeau et al., 1988) involved high subsidence rates and flooding of the Vocontian Basin. In the Vocontian Basin, this MFS is found within the Scarburgense Subzone (de Graciansky et al., 1999); at Aspres-surBuëch this surface corresponds to phosphate nodules (Fig. 2C), which likely indicates low sedimentation rates.

\subsubsection{EST342 drill-core}

The EST342 drill site is located to the west of the Marne valley near Joinville (Haute-Marne, France), $25 \mathrm{~km}$ to the southwest of the ANDRA (Agence Nationale pour la gestion des Déchets Radioactifs) Underground Research Laboratory near Bure, Meuse/Haute-Marne, France. The Callovian-Oxfordian argillites, 65-m thick in the drill-core, span the Middle Callovian (Jason Zone) to the top of the Mariae ammonite zone of the Early Oxfordian, and were cored in their entirety. Here, the Mariae Zone is represented by only $25 \mathrm{~m}$ (Fig. 3, $615.57 \mathrm{~m}$ to $590.10 \mathrm{~m}$ ); ammonite fauna provides a constrained biostratigraphic framework at the horizon scale (Thierry et al., 2006).

Lithologies (Fig. 3C) are composed of approximately 50\% clay minerals, 25\% silt (quartz, feldspar, muscovite) and 25\% carbonate (calcite and dolomite). An enrichment of clays is observed at the base of the Mariae Zone with a concentration of bioclasts, bioturbation, ammonites and burrows. The remainder of the series is represented by black silty bioturbated argillites with some burrows; glauconite and pyrite occur at $\sim 600$ and $\sim 605 \mathrm{~m}$. From $595 \mathrm{~m}$ up, the ammonite fauna is less abundant. In the uppermost $4 \mathrm{~m}$, the series exhibits decimeterscale couplets of carbonate-rich and carbonate-poor beds as in the Aspres section. Two sample gaps occur at $\sim 611$ and $\sim 605 \mathrm{~m}$.

The sequence stratigraphic interpretation for the EST342 section (Fig. 3C) is based on well logging correlations, geochemical analyses, mineralogical studies (Pellenard et al., 1999; Pellenard, 2003; Ferry et al., 2007), and on the interpretation of MS long-term evolution (Huret, 2006). The Mariae Zone is situated within the [Ox0-Ox1] third-order depositional sequence (Hardenbol et al., 1998). Its lower boundary Ox0 is placed around the base of Mariae Zone whereas its upper boundary Ox1 occurs in the Praecordatum Subzone (from Hardenbol et al., 1998). The maximum flooding surface (MFS), which corresponds to a major MFS, is situated in the Scarburgense Subzone (at the scarburgense horizon; e.g., Courville and Collin, 2002). 


\section{Methods}

\subsection{Magnetic susceptibility (MS)}

In the Aspres-sur-Buëch section, the Mariae Zone is 333-m thick. According to GTS2004 this represents a duration of 0.6 myrs. If we assume a constant sedimentation rate through the section, the precession index about 20 kyrs would be recorded in sediment cycles with an average thickness of $\sim 11 \mathrm{~m}$. Thus, to recover a record of the precession index, the sampling interval was fixed conservatively at $0.50 \mathrm{~m}$ ( 22 samples per cycle). Sampling was performed on marls excluding tempestite and nodule levels because they may introduce singular MS peaks that are not representative either for the time sampling or the original magnetic mineral concentrations that were

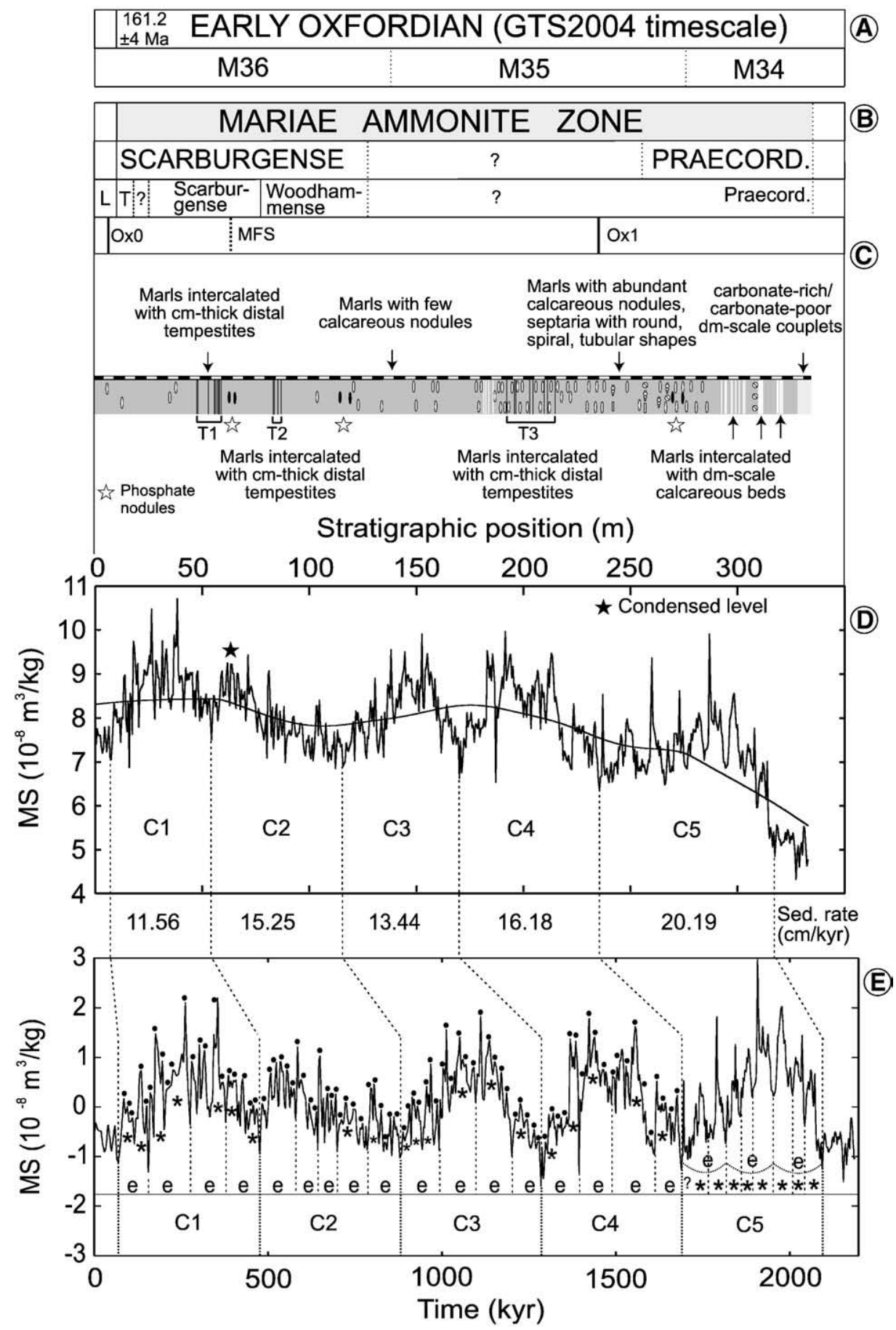

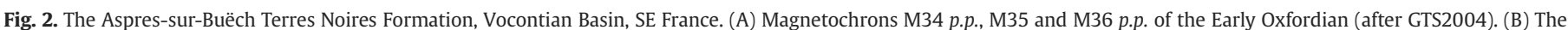

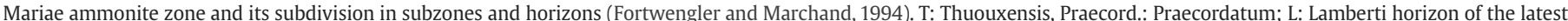

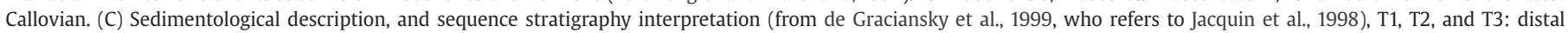

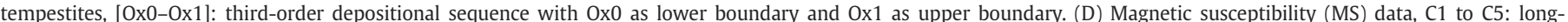

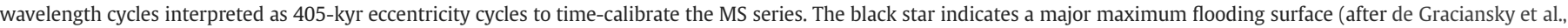

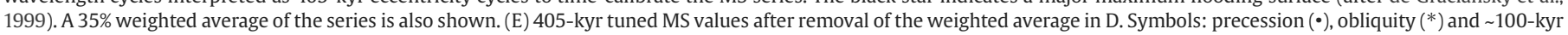
eccentricity (e) 


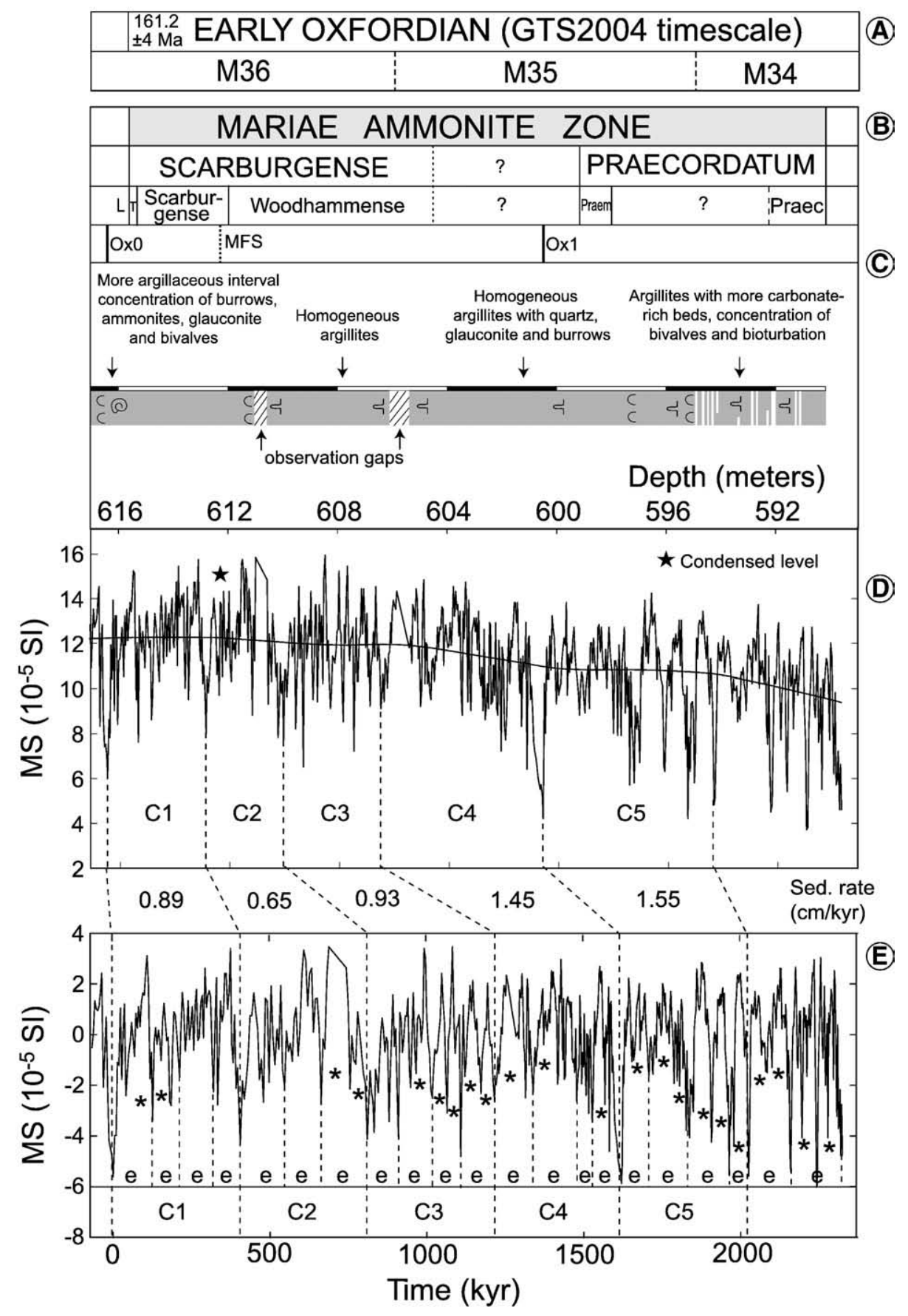

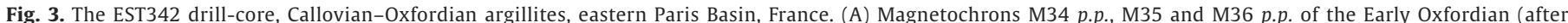

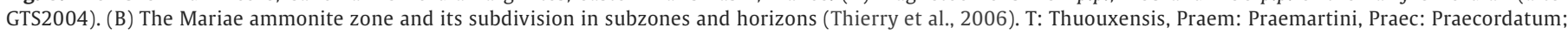

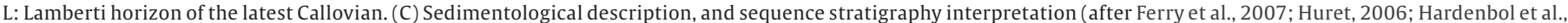

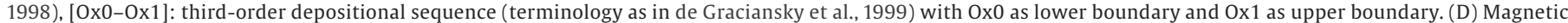

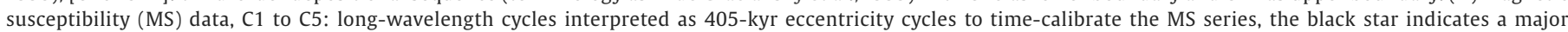

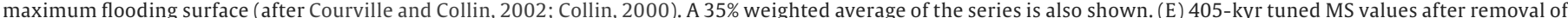
the weighted average in D. Symbols: obliquity $\left(^{*}\right)$ and $\sim 100-$ kyr eccentricity (e).

deposited. The 667 collected samples were measured for MS with a Kappabridge KLY-2. Each sample was measured three times, and the mean of these values is reported after weight normalization. The standard deviation of the analytical error associated with the MS measurements, based on triplicate analyses, is $0.0091 \times 10^{-8} \mathrm{~m}^{3} / \mathrm{kg}$.

For the EST342 drill-core, MS measurements were taken directly on the core and parallel to the strata using a Bartington MS2E1 sensor (sensitivity of $2 \times 10^{-6} \mathrm{SI}$ ). The measurement step was fixed at $0.04 \mathrm{~m}$ to recover a high-resolution record of the precession index ( 21 measurements per cycle, again assuming 0.6 myr duration for the Mariae Zone).

\subsection{Spectral analysis and significance testing}

The MS data are affected by irregular long-term trends which were measured and subtracted by the 35\% weighted average of the series (Figs. 2D, 3D). Following removal of these long-term trends, the data 
were analyzed via spectral analysis (Fig. 4) using the multitaper method (MTM, Thomson, 1982) as implemented in the SSA-MTM Toolkit (Ghil et al., 2002).

Assessment of the relative contributions of signal versus noise in the MS series presents a special challenge. The long-term C1-C5 cycles
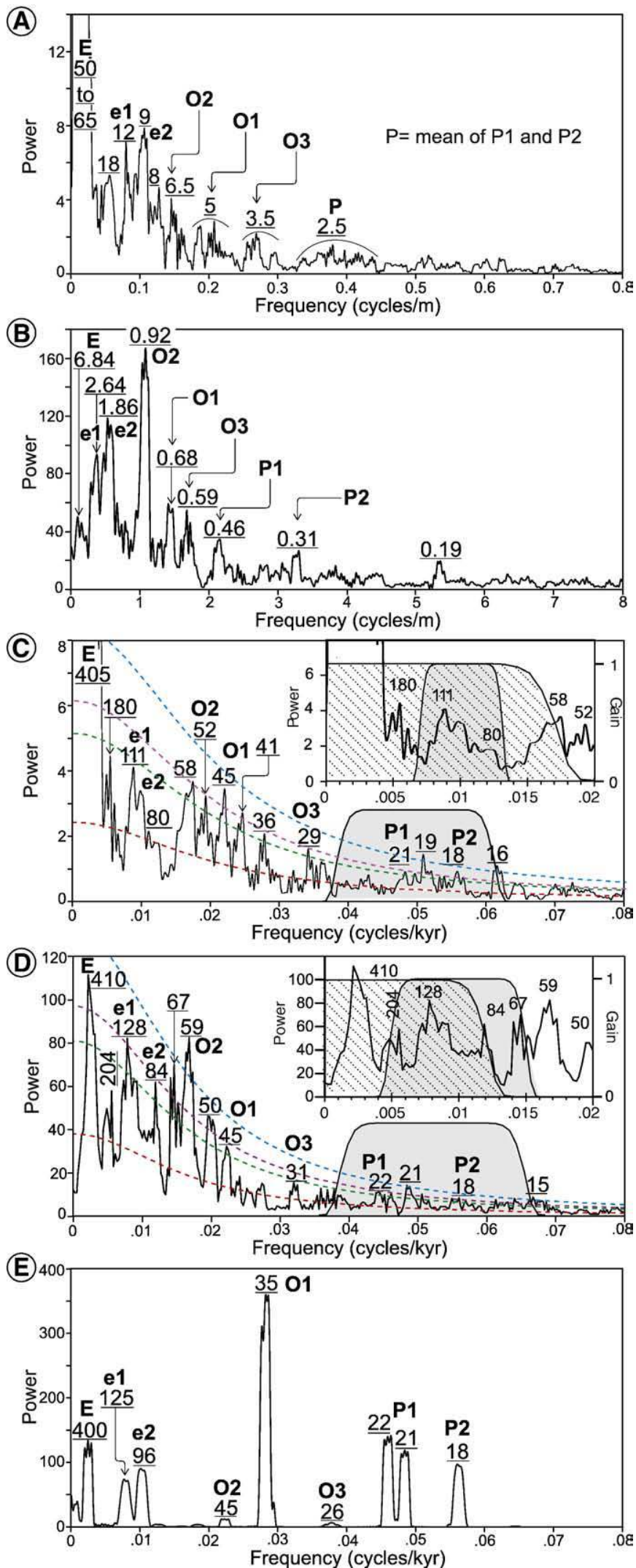

(section 4.1.) overwhelmingly dominate the Aspres series; other regular, higher-frequency variations are also quite visible in both the Aspres and EST342 series (Figs. 2, 3). This rather obvious presence of narrow-band (non-random) signal precludes application of traditional approaches to noise modelling. For example, simple autoregressive (e.g., "red noise") modelling (e.g., Box and Jenkins, 1976) would improperly include signal variance, which is substantial in the modelled noise.

The solution involves diminishing the influence of narrow-band components in the time series prior to noise modelling (Mann and Lees, 1996). This is accomplished through "median-smoothing" the spectrum to suppress elevated power in narrow bands, then fitting a first order autoregressive spectral model to this median-smoothed spectrum. The fitted output constitutes a "robust" estimate of the noise continuum. We used the SSA-MTM Toolkit (Ghil et al., 2002) to carry out robust noise modelling on the tuned versions of the MS series.

\subsection{Amplitude modulation (AM) analysis}

Amplitude modulation (AM) analysis of cyclostratigraphy is an excellent means to assess astronomical forcing. The well known modulation phenomenon is expressed by the precession index which is modulated by the eccentricity. Short eccentricity cycles are also modulated by long eccentricity cycles, and can be registered in the stratigraphic signal. Obliquity modulation also appears in the astronomical signal, although its origin is more complicated, and is unknown for Jurassic times (Laskar et al., 2004).

We applied the technique to the tuned series to look for AM patterns consistent with eccentricity: (1) We filtered the precession index and eccentricity bands using the Taner filter (Taner, 2000); (2) we applied the Hilbert transform to extract the amplitude modulations (AM) of the filtered series; (3) we computed the power spectra of the AM series to seek evidence for eccentricity variation (405-kyr and $\sim 100$-kyr periodicity); and (4) in the case of the precession, we compared the AM series to the low-frequency variations of the original tuned series to cross-check our hypothesis that the long-term C1-C5 cycles (discussion below) follow the 405-kyr eccentricity cycle recorded in the AM precession.

Fig. 4. $2 \pi-M T M$ power spectra, using the multitaper method as implemented in SSAMTM Toolkit (Ghil et al., 2002). Results of robust noise modelling are also shown: Curve $\mathrm{M}$ is the median-smoothed, fitted red noise spectrum (see Section 3.2); the upper 90\%, 95\% and 99\% confidence limits are also shown. For both Aspres and EST342 tuned series, robust noise modelling was carried out with a 0.03 cycles/kyr mediansmoothing window, which represents a bandwidth that is approximately $20 \%$ of the effective Nyquist frequency range (varying between 0.1 to 0.2 cycles/kyr) of the series. Also shown are Taner passbands used to filter the series (Taner, 2000). (A) Detrended magnetic susceptibility (MS) series from Aspres-sur-Buëch (Fig. 2D). Significant peaks are labelled in meter. The high-power $(\sim 90)$ peak at the lowest frequency $(65 \mathrm{~m}$ wavelength) is truncated to emphasize the high-frequency portion of the spectrum. (B) Detrended magnetic susceptibility (MS) series from the EST342 drill-core (Fig. 3D). Significant peaks are labelled in meter. (C) 405-kyr tuned MS series from Aspres-surBuëch (Fig. 2E). Significant peaks are labelled in kyr. The high-power $(\sim 50)$ peak at the lowest frequency (405-kyr period) is truncated to emphasize the high-frequency portion of the spectrum. Shaded area indicates precession passband (cutoff frequencies 0.04 and 0.06 cycles/kyr) used in AM analysis (see text). Inset: spectrum over [0, 0.02 cycles/kyr] and Taner passbands; dashed area depicts the low-pass filter (cutoff frequency 0.017 cycles/kyr) used in Fig. 5A (Curve 1); the shaded area is the passband (cutoff frequencies 0.007 and 0.013 cycles/kyr) used to filter short eccentricity in Fig. 6A (Curve 1). (D) 405-kyr tuned MS series from the EST342 drillcore (Fig. 3E). Significant peaks are labelled in kyr. Shaded area indicates precession passband (cutoff frequencies 0.04 and 0.065 cycles/kyr) used in AM analysis (see text). Inset: spectrum over [0, 0.02 cycles/kyr] and Taner passbands; dashed area depicts the low-pass filter (cutoff frequency 0.012 cycles/kyr) used in Fig. 5A (Curve 3); the shaded area is the passband (cutoff frequencies 0.0055 and 0.015 cycles/kyr) used to filter short eccentricity in Fig. 6A (Curve 3). (E) Earth's orbital parameters, 158.9 to 161.2 Ma B.P., from the nominal La2004 model (Laskar et al., 2004) in ETP format (Imbrie et al., 1984, pp. 296-297). Peaks are labelled in kyr. 


\section{Results}

\subsection{MS variations}

\subsubsection{Aspres-sur-Buëch}

The MS values are relatively low (4.36 to $10.74 \times 10^{-8} \mathrm{~m}^{3} / \mathrm{kg}$ ) and their variations follow a strongly cyclic pattern (Fig. 2D). A decreasing trend up section is linked to a progressive enrichment of the marls with carbonate and dilution from diamagnetism. There are five lowfrequency cycles (C1-C5) superimposed on high-frequency cycles. The thickest cycle (C5) records the highest carbonate content. Comparing $\mathrm{C} 1-\mathrm{C} 5$ cycles to the tempestite intervals (T1, T2, and T3; Fig. 2C): the lower T1 occurs in the interval between $\mathrm{C} 1-\mathrm{C} 2$; T2 occurs in the middle of C2; finally, T3 coincides with the maximum of C4. Thus, tempestite occurrence does not have a consistent relationship to MS C1-C5 cycles.

In Fig. 2C,D we compare C1-C5 MS cycles to the third-order depositional sequences of de Graciansky et al. (1999) who refer to Jacquin et al. (1998) (in Hardenbol et al., 1998): the lower sequence boundary $\mathrm{Ox} 0$ of the third-order sequence [Ox0-Ox1] may correspond to the lower minimum of $\mathrm{C} 1$. The upper sequence boundary $\mathrm{Ox} 1$ of the same sequence [Ox0-Ox1] may correspond to the minimum that separates $\mathrm{C} 4$ and $\mathrm{C} 5$. Finally, the maximum flooding surface (MFS) of [Ox0-Ox1] appears to correspond to relatively high values within $\mathrm{C} 2$, the least regular cycle, supported with a phosphate nodule level. In sum, the C1-C5 MS cycles do not correspond well to the third-order depositional sequences of Jacquin et al. (1998). The one exception, the MFS in the Scarburgense Subzone, is situated within the maximum of C2. This MFS may induce clay condensations. Thus, we infer that fast sea-level rise enhanced the surface clay deposits in the basin, resulting in a reduced accumulation rate over this time interval, as also suggested by the occurrence of the phosphate nodule level.

\subsubsection{EST342}

In the EST342 drill-core, MS values are relatively low between $2 \times 10^{-5}$ and $16 \times 10^{-5} \mathrm{SI}$ (Fig. 3) and follow a long-term evolution similar to other ANDRA drill-cores in the Paris Basin (Huret, 2006). Magnetic mineralogy studies indicate that these low values of MS characterize paramagnetic clay minerals (Huret, 2006) and locally a few contributions of ferrimagnetic minerals like iron sulfides and oxides (Esteban, 2006; Esteban et al., 2006). In the Mariae Zone, the long-term evolution of MS occurs in two stages (Fig. 3D). The first, from the bottom of the series to $611.5 \mathrm{~m}$ is a progressive increase in MS values with a maximum value of $16 \times 10^{-5}$ SI occurring at $611.5 \mathrm{~m}$; this corresponds to the maximum argillaceous content observed in the series (Pellenard et al., 1999; Esteban et al., 2006). The second interval, from $611.5 \mathrm{~m}$ to the top of the series, shows a decrease in MS values reflecting a progressive enrichment in carbonate, similar to Aspres. Low-frequency cycles, 3 to $6 \mathrm{~m}$ thick, designated $\mathrm{C} 1$ to $\mathrm{C} 5$, analogous to those in the Aspres series, are also visible, although with much lower amplitudes. The least thick cycles, $\mathrm{C} 1$ and $\mathrm{C} 2$, at the base of the series are associated with reduced sedimentation across the Callovian/ Oxfordian boundary. As in Aspres, the thickest cycle (C5) records the highest carbonate content.

Study of numerous ANDRA drill-cores indicates a long-term evolution of MS reflecting major transgressive/regressive changes of second and third orders, with the transgressive phases represented by increases in MS and the regressive phases by decreases in MS (Huret, 2006). In this context, the Mariae Zone is situated in a third-order transgressive/regressive cycle. The transgressive phase in the EST342 drill-core starts, as at Aspres, around the base of Mariae Zone (Ferry et al., 2007; Huret, 2006) with an increase of MS values peaking at $611.5 \mathrm{~m}$. The maximum flooding surface (MFS) is situated in the Scarburgense Subzone, precisely at the scarburgense horizon (Collin, 2000; Courville and Collin, 2002). This MFS is at the same stratigraphic level as the MFS interpreted for the Aspres section (Fig. 2C) and the
Terres Noires Formation (de Graciansky et al., 1999). The regressive phase corresponds to the decrease of MS values observed in the middle part of the series from $611.5 \mathrm{~m}$ to $600 \mathrm{~m}$ (after de Graciansky et al., 1999).

\subsection{Time series analysis and modelling of the MS variations}

\subsubsection{Time calibration of $\mathrm{C} 1-\mathrm{C} 5$ cycles}

Applying the GTS2004 0.6 myr Mariae Zone duration to the $333 \mathrm{~m}$ Aspres-sur-Buëch section implies an average sedimentation rate of $55 \mathrm{~cm} / \mathrm{kyr}$ and the prominent $\sim 60$-m thick cycles C1-C5 (Fig. 2) should correspond to a 100-kyr periodicity. This calibration, however, creates challenges in explaining the distribution of power in the MS spectrum, as discussed below. The same problem applies to the EST342 series. We also note that even more expanded sections of the Terres Noires Formation recently measured at Oze and Trescleoux (SE France) reveal cyclic patterns comparable to those at Aspres (Boulila, 2008). These sections extend the $\mathrm{C} 1-\mathrm{C} 5$ cycling theme at a comparable scale into the Middle Oxfordian where finally the 405-kyr calibration of the cycles (up to C10) reconciles with GTS2004 scaling at the top of the Transversarium ammonite zone (Boulila, 2008; Boulila et al., 2008b). These observations, along with several tests presented below, strongly influenced us to favor the C1-C5 calibration to a 405-kyr periodicity.

\subsubsection{Aspres-sur-Buëch}

The power spectrum of the untuned Aspres MS series (Fig. 4A) shows numerous peaks resulting most likely from a variable sedimentation rate. In the 405-kyr tuned MS spectrum (Fig. 4C), e1 and e2 short eccentricity terms are expressed by a broad peak centered at a period of $\sim 100 \mathrm{kyr}$, presumably averaging e1 and e2. P1 and $\mathrm{P} 2$ precession index are assigned to frequencies comparable to those predicted for the Jurassic (compare Figs. $4 \mathrm{C}$ and $\mathrm{E}$ ). In contrast, the obliquity, which is predicted to appear at $1 /(35 \mathrm{kyr}$ ) (Fig. 4E), is evidently not present. Instead, elevated power occurs at numerous frequencies centered near $1 /(50 \mathrm{kyr})$, nowhere close to the predicted obliquity band. Nonetheless, we have tentatively identified these peaks as obliquity; there are persistent cycles at these frequencies throughout the MS series, as shown by the asterisks in Fig. 2E. The scatter of peak frequency is probably due to unsteady sedimentation rates not accounted for by the 405-kyr tuning. These frequencies in the 100-kyr tuning model scale to semi-precession (Table 1A).

At this point, we comment further on the Aspres MS spectrum tuned to $405-\mathrm{kyr}$ and alternatively to $100-\mathrm{kyr}$ (indicated by GTS2004). Referring to Fig. 4C, rescaling the depicted 405-kyr tuned spectrum to a 100-kyr calibration of $\mathrm{C} 1-\mathrm{C} 5$ is a simple matter of dividing the periodicities of the labelled spectral peaks by 4.05 (Table $1 \mathrm{~A}$ ). Consequently, substantial power ( $14 \%$ of the total) is reassigned to the sub-orbital (millennial) band (boxed values in Table $1 \mathrm{~A})$. We compared the two calibrations using ratio testing: if C1-C5 are 405-kyr cycles, then the ratio of $405 \mathrm{kyr}$ to the interpreted short eccentricity components of 111 kyrs and 80 kyrs ranges from 405:111=3.65:1 to $405: 80=5: 06: 1$, compared to the predicted ratios of $405: 128=3.16: 1$ and $405: 96=4.22: 1$. For the $100-\mathrm{kyr}$ calibration, the ratios between short eccentricity and the precession index fall in the range 128:18=7.1:1 and $96: 22=4.36: 1$. The observed ratios (3.65:1 to 5:06:1) fall partly between both ranges, not ruling out either calibration, but being on the slightly lower side, favors the 405-kyr calibration.

As a second test for the 405-kyr calibration, we examined the precession band for amplitude modulations consistent with the orbital eccentricity. The results (Fig. 5) reveal strong AM signal frequencies (Curve 2) at $1 /(400 \mathrm{kyr}$ ) and a significant $1 /(100 \mathrm{kyr})$ component consistent with eccentricity variation. The low-frequency variation (Curve 1) shows that 405-kyr minima of C1-C5 cycles are phase-locked with those of the AM signal; the 100-kyr scale variations, while pronounced, appear less well correlated. The AM spectral peak at $1 /(240 \mathrm{kyr})$ may also be related to a minor eccentricity term (cf. Grippo et al., 2004, their Fig. 7D). In terms of ratios, the AM 
Table 1

Comparison between the MS spectral peaks tuned to 405-kyr (referring to Figs. 4C and D) and alternatively to $100-\mathrm{kyr}$

\begin{tabular}{|c|c|c|c|}
\hline 405-kyr tuned & Orbital periods (Jurassic) & 100-kyr tuned & Orbital periods (Jurassic) \\
\hline \multicolumn{4}{|l|}{$\bar{A}$} \\
\hline 405 & \multirow[t]{2}{*}{ E-405 (405) } & 100.0 & e1/e2-128/95 (128/95) \\
\hline 180 & & 44.44 & $02-54(47.6)$ \\
\hline 111 & e1-128 (128) & 27.41 & $01-41(37.5)$ \\
\hline 80 & e2-95 (95) & 19.75 & $03-29(27.0)$ \\
\hline 58 & & 14.32 & P1-23 (21.8) \\
\hline 52 & \multirow[t]{2}{*}{$02-54(47.6)$} & 12.84 & \multirow[t]{3}{*}{$\mathrm{P} 2-19(18.2)$} \\
\hline 45 & & 11.11 & \\
\hline 41 & \multirow[t]{2}{*}{$01-41(37.5)$} & 10.12 & \\
\hline 36 & & 8.889 & \multirow{6}{*}{$\begin{array}{l}\text { NOTE: } \\
\text { All values in kyr }\end{array}$} \\
\hline 29 & $03-29(27.0)$ & 7.161 & \\
\hline 21 & P1-23 (21.8) & 5.185 & \\
\hline 19 & \multirow[t]{3}{*}{ P2-19 (18.2) } & 4.691 & \\
\hline 18 & & 4.444 & \\
\hline 16 & & 3.951 & \\
\hline \multicolumn{4}{|l|}{$B$} \\
\hline 410 & \multirow[t]{2}{*}{ E-405 (405) } & 100.0 & e1/e2-128/95 (128/95) \\
\hline 208 & & 51.36 & $02-54(47.6)$ \\
\hline 128 & e1-128 (128) & 31.60 & $01-41(37.5)$ \\
\hline 84 & \multirow[t]{2}{*}{ e2-95(95) } & 20.74 & $03-29(27.0)$ \\
\hline 67 & & 16.54 & P1-23 (21.8) \\
\hline 59 & \multirow[t]{2}{*}{$02-54(47.6)$} & 14.57 & \multirow[t]{3}{*}{ P2-19 (18.2) } \\
\hline 50 & & 12.35 & \\
\hline 45 & $01-41(37.5)$ & 11.11 & \\
\hline 31 & $03-29(27.0)$ & 7.654 & NOTE: \\
\hline 22 & \multirow{2}{*}{ P1-23 (21.8) } & 5.432 & \multirow[t]{4}{*}{ All values in kyr } \\
\hline 21 & & 5.185 & \\
\hline 18 & \multirow[t]{2}{*}{ P2-19 (18.2) } & 4.444 & \\
\hline 15 & & 3.704 & \\
\hline
\end{tabular}

(A) Aspres-sur-Buëch, (B) EST342 ANDRA drill-core. Rescaling the depicted 405-kyr tuned spectrum to a $100-\mathrm{kyr}$ tuning of $\mathrm{C} 1-\mathrm{C} 5$ is a simple matter of dividing the periodicities of the labelled spectral peaks by 4.05 . Jurassic orbital periods in parentheses are interpolated from Berger and Loutre (1994), with additional terms from Hinnov (2000). The boxed values indicate significant spectral peaks calibrated to the obliquity band by 405-kyr orbital tuning, and to the sub-orbital (millennial) band by the 100-kyr calibration.

signal components have a ratio of $476: 118=4.03: 1$, which is consistent with long eccentricity:short eccentricity as opposed to short eccentricity:precession index (see previous discussion).

Finally, we repeated the AM procedure on the short eccentricity, seeking evidence for amplitude modulation by the long eccentricity (405-kyr period modulation). This involved high-precision bandpass filtering in the very low-frequency range of the Aspres spectrum (see Fig. 4C inset); the bandpass filtered signal is shown along with its AM envelope in Fig. 6A (Curves 1 and 2). The spectrum of the AM envelope (Fig. 6B) identifies the major cycling at a peak frequency centered on $1 /$ (500 kyr). This could represent 405-kyr cycling. Visual examination of the bandpass filtered signal (Fig. 6A, Curve 1) shows that the lower half of the series does not appear to have a regular modulation (C1 and C2 cycles). In contrast, the upper half shows two successive bundles (within C3 and C4 cycles) of four short eccentricity cycles which could indicate eccentricity. Unfortunately, the series is too short to look for additional very long-term modulations, e.g., 2.4 myr modulations associated with eccentricity variation.

405-kyr calibration results in an average sedimentation rate for the Aspres section of $15.32 \mathrm{~cm} / \mathrm{kyr}$ (Fig. 2D). However, sedimentation rates vary significantly between the C1-C5 cycles. An increase of sedimentation rate up section is associated with enrichment of the marls with carbonate. The condensation between $\mathrm{C} 1$ and $\mathrm{C} 2$ (Fig. 2C,D) corresponds to the forementioned MFS, during which the Vocontian Basin experienced maximum subsidence plus eustatic sea-level rise (de Graciansky et al., 1999). Visual examination of MS variations shows that the $\mathrm{C} 1$ and $\mathrm{C} 2$ cycles are less regular. Especially the $\mathrm{C} 2$ cycle is most likely disrupted by the condensation induced by the MFS. All of these factors likely contribute to the dispersal of spectral peaks in the MS spectrum.

\subsubsection{EST342}

The power spectrum of the untuned EST342 MS series (Fig. 4B) shows numerous peaks resulting most likely from a variable sedimentation rate. In general, spectral peaks occur at wavelengths that are only $\sim 10 \%$ as long as those in Aspres, reflecting the impressive thickness disparity between the two sections $(\sim 25 \mathrm{~m}$ versus $>300 \mathrm{~m}$ ). While the $\mathrm{C} 1-\mathrm{C} 5$ cycles are visually recognizable at $\sim 4$ to $\sim 6 \mathrm{~m}$ intervals (Fig. 3D), the power spectrum detects no significant power at the corresponding frequencies (Fig. 4B, peak E). This is likely the result of the near doubling of C1-C5 cycle thicknesses from bottom to top of the series (Fig. 3C). The dominant spectral peak at $0.92 \mathrm{~m}$ is also visible in the MS series, and in particular gains prominence in $\mathrm{C} 4$ and above.

Remarkably, simple tuning of C1-C5 to 405-kyr intervals collects sufficient power to give $\mathrm{E}$ the highest spectral peak in the tuned

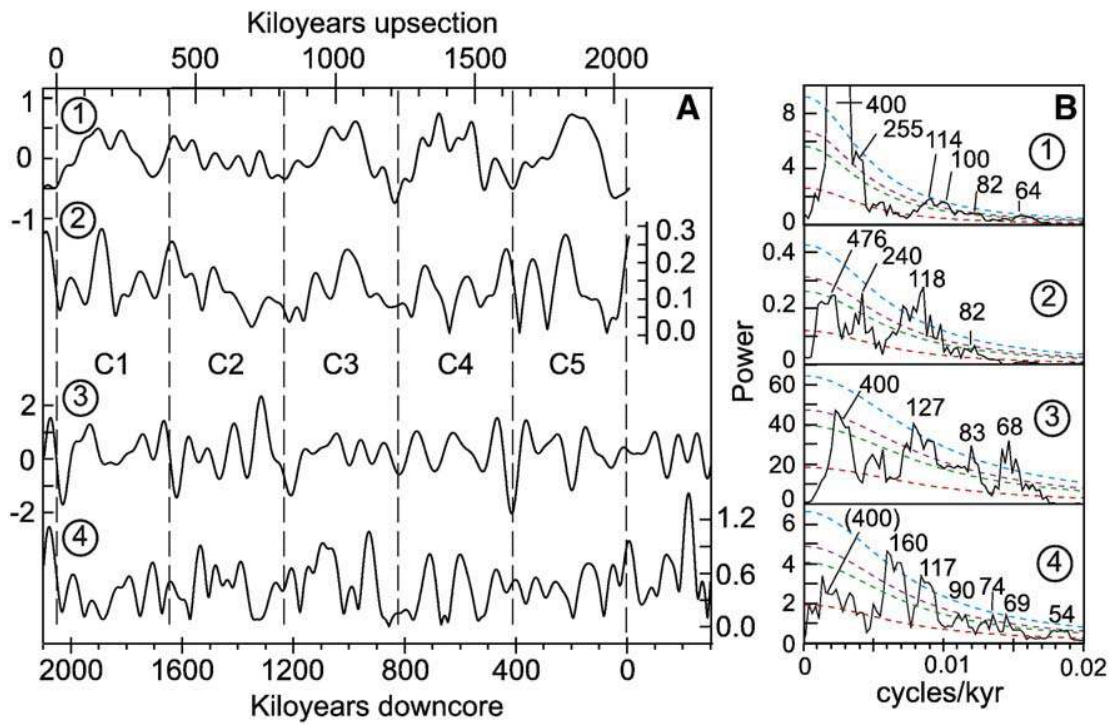

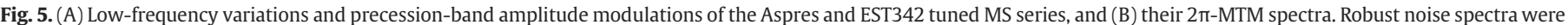

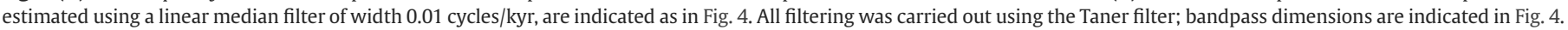

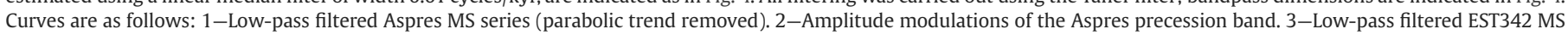
series (parabolic trend removed). 4-Amplitude modulations of the EST342 precession band. 

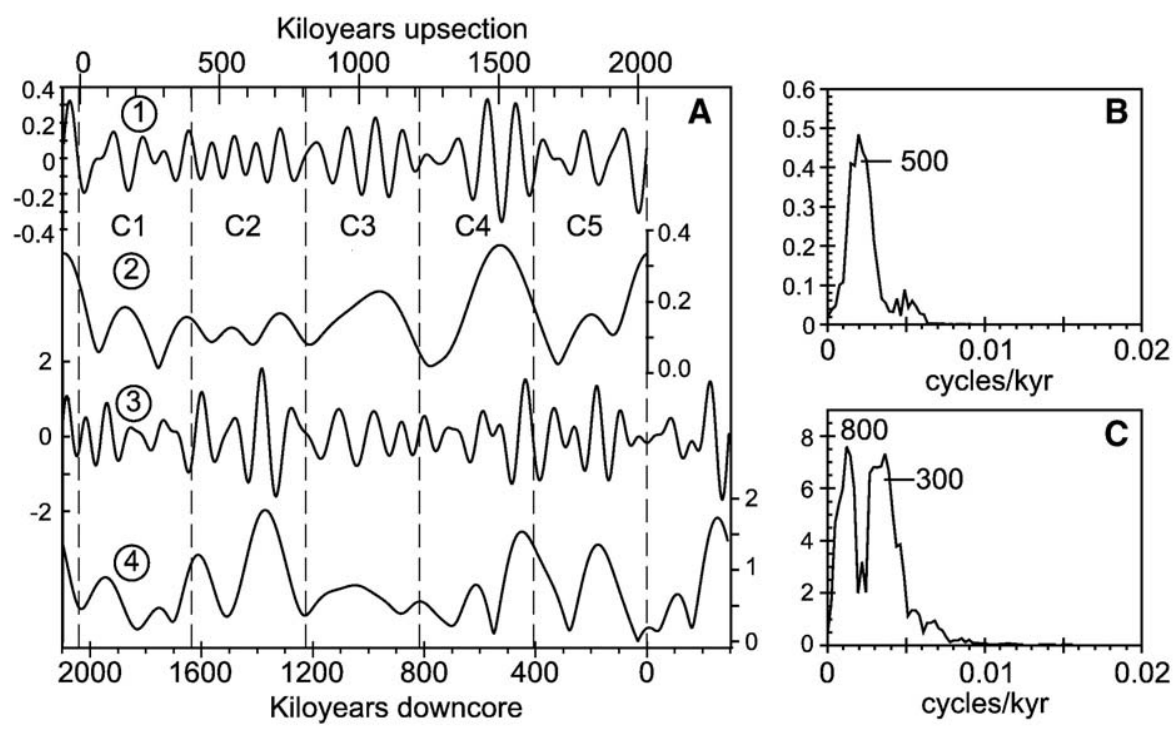

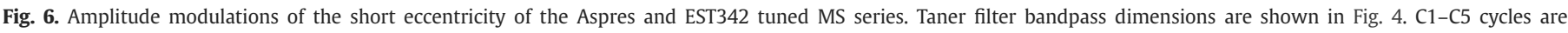

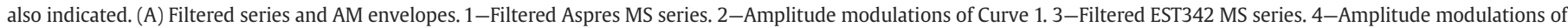
Curve 3. (B) $2 \pi$-MTM power spectrum of Curve 2 in A. (C) $2 \pi-M T M$ power spectrum of Curve 4 in A. Labels in kyr.

spectrum (Fig. 4D). The tuning also disperses power from the $0.92 \mathrm{~m}$ wavelength primarily into the lower frequencies associated with eccentricity. As with the Aspres tuned spectrum, the theoretical obliquity is not borne out by comparable frequencies in the tuned series. Instead, a packet of frequencies centered closer to $1 /(50 \mathrm{kyr})$ is present. Low power peaks associated with precession index frequencies exceed the calculated noise model, and are closely aligned with the predicted precession frequencies (compare Figs. 4D and E).

As in Aspres, 405-kyr tuning (Fig. 4D and Table 1B) focuses spectral peaks into the precession, obliquity, and short eccentricity bands. In contrast, the 100-kyr tuning model calibrates some spectral peaks, with high power, at millennial band (boxed values in Table 1B). Moreover, ratio testing falls in the range of 405-kyr tuning model. For the 405-kyr calibration, the ratios between long and short eccentricity are $410: 128=3.2: 1$ and $410: 84=4.88: 1$ (close to theoretical ratios $3.16: 1$ to $4.22: 1$ ). However, the $100-\mathrm{kyr}$ tuning model gives $128: 18=7.1: 1$ and $84: 22=3.82: 1$.

The AM of the tuned EST342 precession index signal (Figs. 5A and B, Curve 4) shows no significant 405-kyr component but has a strong $100-k y r$ band power, although with a different structure than in the low-pass filtered series (Figs. 5A and B, Curve 3). The AM of the EST342 short eccentricity (Fig. 6A, Curve 4) shows regular modulations, but they progress irregularly, with a heavy loss of amplitude near the middle of the series and not with 405-kyr periodicity (Fig. 6B, Curve 2). The low-pass EST342 series (Fig. 5A, Curve 3) does exhibit 405-kyr cycling, although it is much weaker than that in the low-pass Aspres series (Fig. 5A, Curve 1).

In sum, the AM analysis of EST342 does not show strong evidence for the presence of an eccentricity modulator in either the interpreted precession index or short eccentricity frequency bands. This stands in contrast with the AM results for Aspres, which shows evidence for eccentricity modulation in both AM tests (see above). This negative result could be due to greater sedimentation rate variations affecting the recorded precession index, that cannot be overcome by any single bandpass filter.

\section{Discussion}

\subsection{Duration of the Oxfordian stage and the Mariae ammonite zone}

In GTS2004, the calibration of the 'M-sequence' of marine magnetic anomalies was used to establish the Oxfordian time scale.
The M-sequence time scale is derived from a block model scaled to a single seafloor spreading center, the Pacific "Hawaiian" ridge. There are only three radiometric ages for the entire M-sequence (Ogg and Smith, 2004): $124.6 \pm 0.2 \mathrm{Ma}$ at the top of Chron M0r (Early Aptian), 155.3 \pm 3.4 Ma within Chron M26n (Late Oxfordian-Tethyan), and 167.7 $\pm 1.4 \mathrm{Ma}$, prior to the oldest anomaly M41 (Early Bathonian). These three dates, together with an assumed constant spreading-rate model for the entire pre-Tithonian portion, were used to estimate the absolute ages of the M-sequence anomalies. Biostratigraphic datums and stage boundary dates were determined by a simple projection onto the M-sequence anomalies. For the Late Jurassic, this procedure results in abnormally large uncertainties in the time estimates for biozones and stage boundaries. The boundaries of the Oxfordian stage, which spans anomalies M26 to M36, a particularly unconstrained segment of the M-sequence, are defined only to within \pm 4 myrs.

Quenstedtoceras (Q.) mariae is the first ammonite zone species for the Oxfordian in both the Tethyan and Boreal realms. This biozone is correlated to chrons M36 to M34 (Ogg, 2004), but these assignments are very tenuous. Only one Early Oxfordian section with the Mariae Zone has a published magnetostratigraphy (Ogg et al., 1991). At Zalas (Krakow-Wielun region, Poland), the Mariae Zone is only $20-\mathrm{cm}$ thick, and its polarity is defined by 4 non-equally spaced samples of reversed polarity; at Podleze, the Mariae Zone is $13 \mathrm{~cm}$ thick, and at the top of this short condensed interval 3 samples are of normal polarity. In contrast, the Mariae Zone at Aspres-sur-Buech is 333-m thick, but has not yielded polarity data. Based on the Polish data, a "composite" polarity pattern was roughed in for the Mariae Zone: reversed polarity at the base, a short normal polarity in the middle and a reversed polarity zone at the top (Ogg et al., 1991). This pattern was tentatively correlated to the marine magnetic anomalies, for which the age controls are very poorly constrained (Ogg and Coe, 1997; Ogg and Gutowski, 1996).

Compounding these problems is a rapid occurrence of polarity reversals over this period, which can result in ambiguous correlations. Finally, these geologically old marine magnetic anomalies are weak, and their interpretation as true magnetic reversals is debatable (Tivey et al., 2006). Nonetheless, the Mariae Zone is presently considered to extend from the upper part of Chron M36 through the lower part of M34 (Fig. 2B). Finally, assuming a constant spreading rate for the magnetic lineations, the duration of the Mariae Zone was estimated as 0.6 myrs, with the base of the zone defined at the CallovianOxfordian boundary (Ogg, 2004). Given all of these uncertainties 
and approximations, it is not unreasonable to consider that the 0.6 myr duration assigned to the Mariae Zone in GTS2004 might be questionable.

\subsection{Astronomical calibration of the Mariae ammonite zone}

The question of whether C1-C5 are 405-kyr or 100-kyr cycles is our main problem. GTS2004 points to $100-\mathrm{kyr}$, but the power spectrum of the MS series suggests 405-kyr, at least in terms of being able to explain the majority of spectral power in terms of orbital forcing. The internal MS variations within C1-C5 show consistent patterns that are reminiscent of composite orbital behavior: The power spectra of Hilbert transform envelopes in the two studied sections suggests that the precession index is strongly modulated by short and long eccentricity. Furthermore, there is a consistent $4: 1$ bundling of the $10 \mathrm{~m}$ 'e' cycles into long-wavelength 50 to $65 \mathrm{~m}$ ' $\mathrm{E}$ ' cycles (except for C2 and C5) at Aspres-sur-Buëch. C2 shows a 5:1 bundle; C5 does not exhibit internal bundling per se; 10 regular high-frequency cycles of $10-\mathrm{m}$ wavelength within this cycle suggest that they could be obliquity cycles. We suggest a transition from primary precessioneccentricity to dominant obliquity forcing across C4 to C5.

If the 100-kyr calibration were to hold, it would imply that Jurassic precession has been recorded at a $10 \mathrm{~m}$ stratigraphic (post-compactional) thickness, which is more than an order of magnitude greater than, for example, the $\sim 1 \mathrm{~m}$ thick precession-forced Pliocene Trubi Marl cycles (e.g., Hilgen et al., 1993) or the $\sim 0.6 \mathrm{~m}$ precession-forced Kimmeridgian cycles in the Vocontian Basin (Boulila et al., 2008a). This would indicate an unprecedented rapid (post-compactional) sedimentation rate of $550 \mathrm{~m} /$ myrs for a clay-rich marine marl (with only $10-30 \%$ carbonate) during a geologic age noted for a global crisis in marine carbonate production.

In light of the above considerations, we are skeptical of the GTS2004 calibration of 0.6 myrs for the Mariae Zone, respectively a 100 -kyr calibration for C1-C5. We suggest that a 405-kyr calibration for C1-C5 is equally valid, and this results in a duration estimate of 2.2 myrs for the Mariae Zone.

\subsection{Geological consequences for a long Mariae ammonite zone}

This result-2.2 myrs in this study versus 0.6 myrs in GTS2004could have a significant impact on the spreading-rate model used in GTS2004. In the model, the long-term average spreading rate of the "Hawaiian" ridge in the Pacific was estimated as $\sim 28 \mathrm{~km} / \mathrm{myr}$. Constraints from Early Cretaceous cyclostratigraphy (Huang et al., 1993) imply that the average Early Cretaceous rate was about 25\% slower than the average rate during the Middle-Late Jurassic. Therefore, relative to the long-term average rate, four extended intervals of constant-spreading rate were calculated through the preHauterivian M-sequence (Gradstein et al., 2004, p. 85). Consequently, for the M-sequence older than Chron M23n (mid-Kimmeridgian), the spreading rate of the "Hawaiian" ridge was estimated as $\sim 30 \mathrm{~km} / \mathrm{myr}$. In this study, the Mariae Zone duration is more than three times greater than that indicated in GTS2004. Therefore, the Pacific spreading-rate model may be significantly overestimated for the Early Oxfordian, and our results appeal to a revision of the Msequence model (Boulila et al., 2008b).

Sediment supply and sedimentation rate depend on morphological gradient, climate, erosion rate, organic or inorganic (carbonate, silica, etc.) productivity, and carbonate export from the platform to the basin (e.g., Pittet et al., 2000). These parameters are variable all over the Earth and may interact with different subsidence rates of the various geodynamic settings (Doglioni and Prosser, 1997; Doglioni et al., 1998). The estimated sedimentation rate in the Vocontian Basin from this study is $\sim 150 \mathrm{~m} / \mathrm{myr}$, which is reasonable when compared to those from previous geodynamic studies. For example, for the passive Southern Alps margin, foredeep sedimentation rate was estimated as $\sim 100 \mathrm{~m} / \mathrm{myr}$ (e.g., Doglioni and Prosser, 1997), whereas for the active Apennines margin, foredeep sedimentation rate was estimated as $\sim 3000 \mathrm{~m} / \mathrm{myr}$ (e.g., Doglioni et al., 1998).

Another example from the Kimmeridgian stage, again using a cyclostratigraphic approach in the Vocontian Basin (Boulila et al., 2008a), indicates sedimentation rates of $\sim 30 \mathrm{~m} / \mathrm{myr}$, which is comparable to the results of Doglioni and Prosser (1997).

\section{Conclusions}

High-resolution magnetic susceptibility (MS) analysis of the Early Oxfordian marine marls in the Aspres-sur-Buëch section (Vocontian Basin, SE France) and the EST342 drill-core (eastern Paris Basin) was undertaken to investigate variability and astronomical forcing of detrital input into the basins. The principal results are:

- Astronomical cycles were encoded as variations in detrital input to the basins. Climatically driven weathering of surrounding emergent areas during the Early Oxfordian was a significant source of the detrital (clay) components.

- MS proved to be a powerful tool for detecting cyclic variations in detrital influx within the marl deposits. Spectral analysis of the MS series revealed multiple frequencies that are consistent with orbital forcing.

- The five longest-wavelength cycles C1-C5 were calibrated to the 405-kyr eccentricity cycle, which focused spectral power into the $\sim 100$-kyr eccentricity, obliquity and precession bands. Strong obliquity forcing takes place at both localities near the top of the Mariae Zone (in cycle C5).

- The 405-kyr tuned MS series calibrate the Mariae ammonite zone to a duration of $\sim 2.2$ myrs, whereas GTS2004 assigns only 0.6 myrs. This implies that the durations, as well as the uncertainties, are seriously under-reported in GTS2004 due to lack of adequate chronostratigraphic data.

This work demonstrates the power of cyclostratigraphy of the marine marls in the Vocontian and Paris basins to calibrate the Oxfordian time scale. The interpreted 405-kyr cycles in the MS series correspond to the most stable astronomical (orbital eccentricity) term predicted for Jurassic times (Laskar et al., 2004), and thus constitutes a reliable metronome for the astronomical calibration of this Late Jurassic sedimentary series.

The results contribute to the knowledge of regional tectonics, subsidence, and sedimentary filling of the Vocontian and Paris basins. The astronomical calibration presented here may also lead to improved spreading-rate estimates for the M-sequence model that is currently used to calibrate Jurassic time. Finally, a future intercalibration of an extended astronomical time scale through the entire Terres Noires Formation, with supporting high-precision radiometric dating of recently discovered bentonites in the Terres Noires Formation and the adjacent Paris Basin marls, should provide much improved constraints for the Jurassic time scale.

\section{Acknowledgments}

S. Boulila gratefully acknowledges the French Institute of Petroleum (IFP-school) for support of this work, especially Christian Ravenne. He also acknowledges the "Institut Français de Coopération - Tunis" for support of his PhD Thesis. We are grateful for the thoughtful reviews provided to us by André Strasser, Jean-François Deconinck, and Stephen Meyers, whose deep knowledge and skillful guidance in geological and analytical matters vastly improved our paper. We thank Stéphanie Bregoin (post-graduate student, Ecole des Mines de Paris) who helped us in the field, and Dmitri Kondrashov (UCLA) for assistance with the SSA-MTM Toolkit. We also thank ANDRA (Agence Nationale pour la gestion des Déchets Radioactifs) for allowing us 
access to the EST342 drill-core and data; we acknowledge especially Hervé Rebours (Bure Site) and Alain Trouiller. L.A. Hinnov was supported by US National Science Foundation Grant EAR-0718905.

\section{References}

Artru, P., 1972. Les Terres Noires du Bassin Rhodanien (Bajocien supérieur à Oxfordien moyen) - Stratigraphie, Sédimentologie, Géochimie. Ph.D. Thesis, Claude Bernard University, Lyon, France, 173 p.

Berger, A., Loutre, M.F., 1994. Astronomical forcing through geological time. In: DeBoer, P., Smith, D.G. (Eds.), Orbital forcing and cyclic sequences. Spec. Publ., vol. 19. International Association of Sedimentologists, pp. 15-24.

Boulila, S., 2008, Cyclostratigraphie des séries sédimentaires du Jurassique supérieur (Sud-Est de la France, Nord de la Tunisie): contrôle astro-climatique, implications géochronologiques et séquentielles. Ph.D. Thesis, Pierre et Marie Curie University, Paris, France, 313 pp.

Boulila, S., Galbrun, B., Hinnov, L.A., Collin, P.Y., 2008a. High-resolution cyclostratigraphic analysis from magnetic susceptibility in a Lower Kimmeridgian (Upper Jurassic) marl-limestone succession (La Méouge, Vocontian Basin, France). Sediment. Geol. 203/1-2, 54-63.

Boulila, S., Ogg, J.G., Przybylski, P.A., Galbrun, B., Hinnov, L.A., 2008b. Pacific spreading rates during Middle Jurassic through Early Cretaceous: astronomical cycle-derived durations of M-sequence polarity chrons. Meeting of the GSA, October 2008.

Box, G.E.P., Jenkins, G.M., 1976. Time series analysis. Forecasting and control. HoldenDay, San Francisco.

Cecca, F., Martin Garin, B., Marchand, D., Lathuiliere, B., Bartolini, A., 2005. Paleoclimatic control of biogeographic and sedimentary events in Tethyan and peri-Tethyan areas during the Oxfordian (Late Jurassic). Palaeogeogr. Palaeoclimatol. Palaeoecol. 222, 10-32.

Collin, P.Y., 2000. Environnements, géochimie et processus de formation de series condensées au Callovo-Oxfordien: du Bassin de Paris à des considerations globales. Ph.D. Thesis, Bourgogne University, Dijon, France, 283 pp.

Collin, P.Y., Courville, P., 2006. Sedimentation and palaeogeography of the eastern part of the Paris Basin (France) at the Middle-Late Jurassic boundary. C.R. Géosci., Paris 338, 824-833.

Collin, P.Y., Loreau, J.P., Courville, P., 2005. Depositional environments and iron ooid formation in condensed sections (Callovian-Oxfordian, south-eastern Paris Basin, France). Sedimentology 52, 969-985.

Courville, P., Collin, P.Y., 2002. Taphonomic sequences: a new tool for sequence stratigraphy. Geology 30, 511-514.

Curnelle, M., Dubois, P., 1986. Evolution mésozoïque des grands bassins sédimentaires français: bassin de Paris, d'Aquitaine et du Sud-Est. Bull. Soc. Géol. France 8 (4), 529-546 II.

De Graciansky, P.C., Dardeau, G., Bodeur, Y., Elmi, S., Fortwengler, D., Jacquin, T., Marchand, D., Thierry, J., 1999. Les Terres Noires du Sud-Est de la France (Jurassique moyen et supérieur), interprétation en termes de stratigraphie séquentielle. Bulletin du Centre de Recherche d'Exploration et de Production, Elf Aquitaine, 22, t. 1, pp. 35-69.

Dardeau, G., Atrops, F., Fortwengler, D., de Graciansky, P.C., Marchand, D., 1988. Jeu de blocs et tectonique distensive au Callovien et à l'Oxfordien dans le bassin du SudEst de la France. Bull. Soc. Géol. France 8 (5), 771-777 IV.

Debrand-Passard, S., Courbouleix, S., Lienhardt, M.J., 1984. Synthèse géologique du SudEst de la France. Mémoire B.R.G.M. 614 pp.

Dercourt, J., Zonenshain, P., Ricou, L.-E., Kazmin, G.V., Le Pichon, X., Knipper, A.L., Grandjacquet, C., Sborshchikov, I.M., Boulin, J., Savostin, L.-A., Westphal, M., Lauer, J.-P., 1985. Présentation de neuf cartes paléogéographiques au 1/ 20000000 ème s'étendant de l'Atlantique au Pamir pour la période du Lias à l'Actuel. Bull. Soc. Géol. France 8, 637-652.

Dercourt, J., Ricou, L.E., Vrielynck, B., 1993. Atlas Tethys palaeoenvironmental maps. Gauthier-Villars Publications, Paris, 307 pp., 14 maps, 1 pl.

Doglioni, C., Prosser, G., 1997. Fold uplift versus regional subsidence and sedimentation rate. Mar. Pet. Geol. 14 (2), 179-190.

Doglioni, C., D, Agostino, N., Mariotti, G., 1998. Normal faulting vs regional subsidence and sedimentation rate. Mar. Pet. Geol. 15, 737-750.

Dromart, G., Garcia, J.-P., Gaumet, F., Picard, S., Rousseau, M., Atrops, F., Lécuyer, C. Sheppard, S.M.F., 2003. Perturbation of the carbon cycle at the Middle/Late Jurassic transition: geological and geochemical evidence. Am. J. Sci. 303, 667-707.

Esteban, L., 2006. Anisotropie magnétique et de porosité des argilites du CallovoOxfordien du laboratoire souterrain de l'Andra (Meuse/Haute-Marne, Bassin de Paris). Ph.D. Thesis, Toulouse University, Toulouse, France, 302 pp.

Esteban, L., Bouchez, J.-L., Trouiller, A., 2006. The Callovo-Oxfordian argillites from eastern Paris Basin: magnetic data and petrofabrics. C.R. Geosci., Paris 338, 867-881

Ferry, S., Pellenard, P., Collin, P.Y., Thierry, J., Marchand, D., Deconinck, J.F., Robin, C., Carpentier, C., Durlet, C., Curial, A., 2007. Synthèse des données stratigraphiques récentes sur les formations bathoniennes à oxfordiennes de l'Est du Bassin de Paris. Mém. Soc. Géol. France 178, 37-57.

Fortwengler, D., Marchand, D., 1994. Nouvelles unités biochronologiques de la zone à Mariae (Oxfordien inférieur). Geobios, M.S. 17, 203-209.

Ghil, M., Allen, R.M., Dettinger, M.D., Ide, K., Kondrashov, D., Mann, M.E., Robertson, A., Saunders, A., Tian, Y., Varadi, F., Yiou, P., 2002. Advanced spectral methods for climatic time series. Rev. Geophys. 40 (1), 3.1-3.41.

Gradstein, F.M., Ogg, J.G., Smith, A.G. (Eds.), 2004. A geologic time scale 2004, part III. geologic periods, section 18: the Jurassic period. Cambridge University Press, pp. 307-343.
Grippo, A., Fischer, A., Hinnov, L.A., Herbert, T.D., Premoli Silva, I., 2004. Cyclostratigraphy and chronology of the Albian stage (Piobocco core, Italy). Society of sedimentary geology. SEPM Spec. Publ. 81, 57-61.

Hallam, A., 1988. A reevaluation of Jurassic eustasy in the light of new data and the revised Exxon curve. In: Wilgus, C.K., Hastings, B.S., Kendall, C.G., Posamentier, H.W., Ross, C.A van Wagoner, J.G. (Eds.), Sea level changes: an integrated approach. SEPM, Spec. Publ. vol. 42, pp. 261-273.

Hardenbol, J., Thierry, J., Farley, M.B., Jacquin, T., de Graciansky, P.C., Vail, P.R., 1998 Mezozoic and Cenozoic sequence chronostratigraphic framework of European basins. SEPM, Spec. Publ. 60 pp, Tulsa, OK, 8 charts.

Hilgen, F., Lourens, L.J., Berger, A., Loutre, M.-F., 1993. Evaluation of the astronomically calibrated time scale for the Late Pliocene and earliest Pleistocene. Paleoceanography 8, 549-565.

Hinnov, L.A., 2000. New perspectives on orbitally forced stratigraphy. Ann. Rev. Earth Planet. Sci. 28, 419-475.

Hinnov, L.A., Ogg, J.G., 2007. Cyclostratigraphy and the astronomical time scale. Stratigraphy 4, 239-251.

Huang, Z., Ogg, J.G., Gradstein, F.M., 1993. A quantitative study of Lower Cretaceous cyclic sequences from the Atlantic Ocean and the Vocontian Basin (SE France). Paleoceanography 8, 275-291.

Huret, E., 2006. Analyse cyclostratigraphique des variations de la susceptibilité magnétique des argilites callovo-oxfordiennes de l'Est du Bassin de Paris: application à la recherche de hiatus sédimentaires. Ph.D. Thesis, Pierre et Marie Curie University, Paris, France, 321 pp.

Imbrie, J., Hays, J.D., Martinson, D.G., McIntyre, A., Mix, A.C., Morely, J.J., Pisias, N. G., Prell, W.L., Shackleton, N.G., 1984. The orbital theory of Pleistocene climate: support from a revised chronology of the marine $\delta^{18} \mathrm{O}$ record. In: Berger, A.L., Imbrie, J., Hays, J.D., Kukla, G., Saltzman, B. (Eds.), Milankovitch and climate, part 1. D. Reidel Publishing Co., Dordrecht, pp. 269-305.

Jacquin, T., Dardeau, G., Durlet, C., de Graciansky, P.C., Hantzpergue, P., 1998. The North Sea cycle: an overview of 2 nd order transgressive/regressive facies cycles in Western Europe. SEPM Spec. Publ. 60, 445-446.

Laskar, J., Robutel, P., Joutel, F., Gastineau, M., Correia, A.C.M., Levrard, B., 2004. A longterm numerical solution for the insolation quantities of the Earth. A \& A 428 261-285.

Lorin, S., Courville, P., Collin, P.Y., Thierry, J., Tort, A., 2004. Modalités de réinstallation d'une plate-forme carbonatée après une crise sédimentaire: Exemple de la limite Oxfordien moyen - Oxfordien supérieur dans le Sud-Est du Bassin de Paris. Bull. Soc. Géol. France 175 (3), 289-302.

Mann, M.E., Lees, J.M., 1996. Robust estimation of background noise and signal detection in climatic time series. Clim. Change 33, 409-445.

Norris, M., Hallam, A., 1995. Facies variations across the Middle-Upper Jurassic boundary in Western Europe and the relationship to sea-level changes. Paleogeogr. Paleoclimatol. Paleoecol. 116, 189-245.

Ogg, J.G., 2004. The Jurassic period. In: Gradstein, F., Ogg, J., Smith, D. (Eds.), A Geologic time scale 2004. Cambridge University Press, Cambridge, pp. 307-343.

Ogg, J.G., Coe, A., 1997. Oxfordian magnetic polarity time scale. EOS Transact. AGU 78 F186.

Ogg, J.G., Gutowski, J., 1996. Oxfordian and Lower Kimmeridgian magnetic polarity time scale. GeoRes. Forum 1-2, 406-414.

Ogg, J.G., Smith, A., 2004. The geomagnetic polarity time scale. In: Gradstein, F., Ogg, J. Smith, D. (Eds.), A geologic time scale 2004. Cambridge University Press, Cambridge, pp. 63-86.

Ogg, J.G., Steiner, M.B., Wieczorek, J., Hoffmann, M., 1991. Jurassic magnetostratigraphy, 4. Early Callovian through Middle Oxfordian of the Krakow Uplands (Poland). Earth Planet. Sci. Lett. 104, 488-504.

Pellenard, P., 2003. Message terrigène et influences volcaniques au Callovien-Oxfordien dans les bassins de Paris et du Sud-Est de la France. Publ. Soc. Géol. Nord 31362 pp.

Pellenard, P., Deconinck, J.-F., 2006. Mineralogical variability of Callovo-Oxfordian clays from the Paris Basin and the Subalpine Basin. C.R. Geosci., Paris 338 854-866.

Pellenard, P., Deconinck, J.-F., Marchand, D., Thierry, J., Fortwengler, D., Vigneron, G., 1999. Contrôle géodynamique de la sédimentation argileuse du CallovienOxfordien moyen dans l'Est du bassin de Paris: Influence eustatique et volcanique. C.R. Geosci., Paris 328, 807-813.

Pellenard, P., Deconnick, J.-F., Huff, W.D., Thierry, J., Marchand, D., Fortwengler, D. Trouiller, A., 2003. Characterization and correlation of Upper Jurassic (Oxfordian) bentonite deposits in the Paris Basin and the Subalpine Basin, France. Sedimentology $50,1035-1060$.

Pittet, B., Strasser, A., Mattioli, E., 2000. Depositional sequences in deepshelf environments: a response to sea-level changes and shallow-platform carbonate productivity (Oxfordian, Germany and Spain). J. Sed. Res. 70 (2), 392-407.

Taner, M.T., 2000. Attributes Revisited, Technical Publication. Rock Solid Images, Inc., Houston, Texas. URL: http://www.rocksolidimages.com/pdf/attrib_revisited.htm.

Thierry, J., Marchand, D., Fortwengler, D., Bonnot, A., Jardat, R., 2006. Les ammonites du Callovo-Oxfordien des sondages ANDRA dans l'Est du Bassin de Paris: synthèse biochronostratigraphique, intérêts paléoécologique et paléobiogéographique. C.R. Geosci., Paris 338, 834-853.

Thomson, D.J., 1982. Spectrum estimation and harmonic analysis. Proc. IEEE 70 1055-1096.

Tivey, M.A., Sager, W.W., Lee, S.-M., Tominaga, M., 2006. Origin of the Pacific Jurassic quiet zone. Geology 34 (9), 789-792.

Tribovillard, N., 1986. Géochimie organique et minérale dans les Terres Noires calloviennes et oxfordiennes du bassin dauphinois (France SE): mise en évidence de cycles climatiques. Bull. Soc. Géol. France 8 (1), 141-150 IV. 
Tribovillard, N., 1988, Contrôles de la sédimentation marneuse en milieu pélagique semi-anoxique. Exemples dans le Mésozoïque du Sud-Est de la France et de l'Atlantique. Ph.D. Thesis, Claude Bernard University, Lyon I, France, 116 p.

Tribovillard, N., Ducreux, J.-L., 1986. Mise en évidence de cycles climatiques de 100000

et 400000 ans dans les Terres Noires (Callovien inférieur à Oxfordien moyen) du bassin dauphinois (France, Sud-Est). C.R. Geosci., Paris 303 (20), 1807-1812 II.
Weedon, G.P., Jenkyns, H.C., Coe, A.L., Hesselbo, S.P., 1999. Astronomical calibration of the Jurassic time-scale from cyclostratigraphy in British mudrock formations. Phil. Trans. R. Soc. Lond. 357, 1787-1813.

Ziegler, P.A., 1988. Evolution of the Arctic-North Atlantic and the Western Tethys. Am. Assoc. Pet. Geol., Mem. 43198 pp. 